\title{
REPENSANDO A IMAGINAÇÃO CRIMINOLÓGICA E OS MECANISMOS DE LUZ E SOMBRA DOS ESTADOS SOBERANOS NA MODERNIDADE
}

\author{
RETHINKING THE CRIMINOLOGICAL IMAGINATION \\ AND THE MECHANISMS OF LIGHT AND SHADOW \\ FROM THE SOVEREIGN STATES IN MODERNITY
}

\author{
Álvaro Filipe Oxley da Rocha \\ Tiago Lorenzini Cunha
}

\section{RESUMO}

Durante os últimos dois séculos, os Estados-nação foram capazes de reunir diversos mecanismos técnico-científicos de luz e sombra a fim de reproduzir o antigo (e ainda contemporâneo) modelo humanístico e iluminista de proteção da ordem social, por meio do Leviatã hobbesiano. Além disso, criaram - ao mesmo tempo que reforçam - uma determinada imaginação criminológica de guerra, invisível tanto à intelectualidade acadêmica (juristas, criminólogos, etc.) quanto à hegemonia histórica, voltada para a ideologia dos vencedores. Por esse motivo, este estudo repensa essa imaginação de guerra e de morte utilizada pelos Estados soberanos em face do projeto moderno, no sentido de trazer à tona a problemática que envolve os crimes praticados pelas agências de controle oficial, isto é, os Estados-nação e os Mercados Globais. Paralelamente, também se objetiva contestar a passividade da Criminologia contemporânea, de forma a colocá-la em tensão com sua própria disciplina, questionando, assim, seu logos; os crimes que deixou de estudar; os limites dessa disciplina; entre outras responsabilizações políticas e práticas. Para tanto, optamos pelo 
método de pesquisa bibliográfica, de modo a estabelecer paralelos teóricos e práticos similares entre os trabalhos de Benjamin, Bourdieu (2014) e Young (2011) em relação a outras teorizações tradicionais, para a análise da temática do presente estudo.

Palavras-chave: Estados-nação. Luz e sombra. Criminologia. Leviatã.

\section{ABSTRACT}

During the past two centuries, nation-states were able to bring together various technical-scientific mechanisms of light and shadow in order to reproduce the old (and still contemporary) humanistic and illuminist model of protection of the social order through the Hobbesian Leviathan. In addition, they created - at the same time reinforce - a certain criminological imagination of war, invisible both to the academic intelligentsia (jurists, criminologists, etc.) and to historical hegemony, focused on the ideology of the victors. For this reason, this work seeks to rethink the imagination of war and death used by sovereign states in relation to the modern project, in order to shed light on the worst crimes committed by the official control agencies, that is, the genocides that were omitted by both the nation-states and the Global Markets. At the same time, we also want to challenge the passivity of contemporary criminology, so as to place it against the wall of its own discipline, questioning its logos, the crimes it purposely left to study, and the limits of that discipline, among other political and practical responsibilities. To this end, we have opted to use the method of bibliographic research, in order to establish similar theoretical and practical parallels between the works of Benjamin, Bourdieu (2014) and Young (2011) in relation to other traditional theorizations, for the analysis of the theme of the present study.

Keywords: Nation-states. Light and shadow. Criminology. Leviathan.

\section{INTRODUÇÃo}

Questionando modelos discursivos correntes e os seus fundamentos, Mate (2011), a partir das teses benjaminianas, ${ }^{1}$ convida-nos à reflexão. Nesse ato coloca-nos o desafio de problematizar a história que é contada a partir do viés do progresso humanístico e iluminista - imortalizado nos livros oficiais, voltados à contemplação da imortalidade temporal do colonizador ou do dominador na modernidade. Inversamente, o 
autor propõe-nos a história esquecida, invisível, sacrificada em face da necessidade da construção de uma ordem social limpa, homogênea e racional. Isso porque a perspectiva higienista defende uma falsa noção de universalidade de direitos e de garantias, haja vista a impossibilidade, nessa perspectiva, de que todos sejam cidadãos perante a máquina acelerada do "progresso". (Re)Pensar a legitimidade dos Estados-nação para governarem e estruturarem a vida social, é um desafio porque implica a compreensão de seus vários mecanismos técnico-científicos de luz e sombra, responsáveis pelo desenvolvimento de uma determinada "imaginação criminológica" (YOUNG, 2011), racionalizante e de guerra, pertencente e capaz de produzir e de reproduzir um verdadeiro Leviatã contemporâneo.

Como consequência desse quadro, como afirma Bernal Sarmiento (et al., 2014), a Criminologia precisa ser chamada ao centro do debate em questão, haja vista a sua possibilidade de explicar, por meio de seus intelectuais, o porquê de seu "desinteresse" (MORRISON, 2014, p. 224) em visibilizar, em seus relatos, os crimes em massa e os genocídios praticados contra a humanidade durante os últimos dois séculos. Atos esses instrumentalizados pela lógica de guerra hobbesiana e progressista do Estado moderno, tais como o genocídio do "Holocausto nazi”, ocorrido na Alemanha (1933-1945); as mortes nas Grandes Guerras do Camboja; as atrocidades do fascismo, na Itália; as implicações da ditadura franquista, na Espanha; as matanças dos opositores políticos, na União Soviética; o genocídio em Bangladesh; as torturas e os desaparecimentos nas ditaduras latino-americanas; as guerras de libertação na África; a barbárie dos conflitos na América Central e na Colômbia. Outras tantas "limpezas étnicas" poderiam ser mencionadas na manobra para a imposição de uma determinada imagem do civilizado, centrada em uma ideia de preservação de uma zona, em tese, neutra e livre de conflitos (BERNAL SARMIENTO, et al., 2014, p. 40; 43 e ss.).

Por outro lado, em relação à urgência e à complexidade desse termo “imaginação criminológica” (YOUNG, 2011), cabe, neste artigo, questionar as razões dessa "passividade" da Criminologia em abster-se de denunciar os genocídios que ocorreram nos séculos XIX e XX - como explica Morrison (2012, p. 2-4; 58 e ss.). Além disso, é oportuno problematizar os motivos para essa repetição matemática/equacional, positivista - e nada criativa 
- sobre a qual está edificado o estatuto criminológico atual, ilusoriamente "crítico" (YOUNG, 2011, 224-225). Ilusoriamente por que o que está em discussão é o logos da Criminologia, enquanto legitimidade científica, desde o ponto de vista do objeto de estudo e da análise teórica e/ou prática que a sustenta.

Se tal constatação for verdade, isso significará dizer, segundo Zaffaroni, que em virtude da negligência histórica e política da Criminologia em estudar tais crimes massivos contra a humanidade, talvez fosse o caso de responsabilizar essa disciplina de estudo, a fim de desenvolver uma "Criminologia prática [política] com base teórica" (ZAFFARONI, 2014, p. 214). Por outro lado, entendemos que esse posicionamento implica uma série de questionamentos que podem ser levantados: quais problemáticas que podem ser extraídas da produção de uma Criminologia prática de fundamento teórico, e de uma Criminologia teórica com razão prática? Verticalmente pensando, de quais crimes deve se ocupar a Criminologia? A qual imaginação deve limitar-se, local ou global? De que modo podemos avançar na formação de uma Criminologia para além da Criminologia? Ou ainda, provocativamente, comportará tal disciplina - por ser naturalmente "interdisciplinar" (HAYWARD e YOUNG, 2007, p. 102) - outras áreas do conhecimento e diferentes temáticas dentro de sua esfera analítica? Se essa hipótese for verdadeira (Criminologia que comporta diferentes interfaces), trará como resultado o rompimento epistemológico de seu pensar?

Apoiados nessas questões de pesquisa, propomos pensar outra "perplexidade" global (SANTOS, 2000, p. 20 e ss.) derivada da imagem criminológica do Leviatã e de seus mecanismos de luz e sombra, compreendida por nós como principal dilema dos Estados Soberanos na modernidade. Especificamente, falamos da "deterioração" das instituições sociais e de suas linguagens (imagens) racionalizantes e objetivas. Cenário esse responsável por dificultar os sujeitos a encontrarem seja sua identidade, de modo individual, seja o sentido, entendido global e coletivamente, em um tempo de constantes transformações e manipulações neoliberais. Paralelamente, tratamos ainda do outro lado desse dilema dialético, a necessidade do Estado de continuar justificando a sua existência por meio de uma imagem racional (o Direito ou as leis), a fim de que possa ter condições de forjar "objetividades e subjetividades", 
"coisas e cérebros", isto é, promover uma lógica de subordinação recíproca porque treina indivíduos a agir e a pensar (habitus) segundo determinadas categorias do pensamento (BOURDIEU, 2014, p. 78; 166; 250).

Partindo do pressuposto de que o Direito é um mecanismo técnicocientífico (racional) de dominação (WEBER, 2004, p. 30-31; 61), questionamos: em que medida ele é capaz de iluminar ou obscurecer aspectos da vida social, tanto no sentido de mostrar-se como um instrumento de defesa e de organização de uma ordem civilmente construída (a proteção dos vínculos de "solidariedade social" pelo Direito) ${ }^{2}$ quanto de destruição contínua de tudo aquilo que não condiz com a imagem criminológica de base hobbesiana. Essa problematização é oportuna para pensar sobre os genocídios praticados pelos Estados e pelos Mercados Globais, que encobriram tais crimes com o próprio manto do discurso oficial e positivo do Estado (as leis). Colocaram-se na tarefa de separar o trauma de sua área de atuação, de forma a negar os eventos bárbaros que abalaram a sua linguagem (jurídica), por exemplo, durante todo o século XX (SHOSHANA, 2014, p. 22-23).

A fim de que tenhamos condições de aprofundar nossas investigações, é importante ressaltar nossa escolha metodológica. Além das diretrizes teóricas defendidas por Young sobre a "imaginação criminológica” (2011, p. 4 e ss.), pensamos que, se desejamos conhecer aquilo que pode ser definido como a sombra dos conceitos técnico-científicos, necessitamos, então, examinar as relações de poder decorrente da história das instituições, no sentido de uma genealogia, para esclarecer processos de (re)construção do imaginário criminológico. Assim, precisamos repousar nossa atenção sobre as formas de dominar e de ser dominado pelo mundo em relação aos agentes sociais, incorporados por uma lógica racionalizante e impessoal. Essa questão envolve tudo aquilo que é pouco iluminado de forma interessada ou proposital e que se caracteriza como uma tentativa de edificação de uma "adesão dóxica". Podemos dizer que tal cenário configura um sistema social que é esquecido dentro dos sujeitos e que permite negar a possibilidade do espaço das perguntas (BOURDIEU, 2014, p. 250 e ss.) e dos "processos de ruínas e cadáveres" da história (MATE, 2011, p. 22). 
Em outros termos, sendo essa imaginação criminológica o produto ou o resultado formado a partir de discursos ou conceitos técnico-científicos e históricos de poder e de dominação do outro pelos Estados-nação e pelo Mercados globais na modernidade, uma das formas pelas quais podemos tomar consciência desses estratégias e processos simbólicos é através da desnaturalização da história (isto é, o seu confrontamento crítico), acerca de quem, como e por que nos domina. Diante desse contexto é que optamos pelo método de pesquisa bibliográfica, no sentido de delimitar paralelos teóricos e práticos em comum entre os trabalhos de Benjamin (MATE, 2011), Bourdieu (2014) e Young (2011) com outras perspectivas a serem analisadas neste estudo, a fim de organizar a nossa compreensão criminológica (ou a falta proposital dela, sustentada por determinadas agências de controle social) acerca das consequências históricas e cotidianas em ignorarmos, enquanto intelectuais e agentes sociais, o lado obscuro dos discursos criminológicos (de poder/dominação) que patrocinam a lógica Leviatã contemporâneo na modernidade, quais sejam: os genocídios e outros crimes praticados pelos mais poderosos.

Ademais, sabemos que existem diferenças teóricas entre o projeto genealógico de Benjamin (historiador), de Bourdieu (sociólogo) e de Young (criminólogo), à exemplo da opção metodológica de Bourdieu (2014, p. 166-250; 2008, p. 107-108) em atribuir mais destaque a uma genealogia da história das instituições e do modo delas estruturarem a vida social (o que formam e o que as sustentam), bem como, já no caso de Benjamin, este procura construir um conceito de história, a partir de uma genealogia da história esquecida pela história (uma história para além de si mesma), trazendo sempre à iluminação aqueles sujeitos que ficaram no calcanhar histórico da máquina moderna, progressista e difusora da visão colonial e dominadora dos processos de opressão e de barbárie contínua na modernidade (MATE, 2011, p. 176 e ss.; 188-189). No caso de Young (2011), porém, esse desenvolveu uma genealogia da raízes históricas e contemporâneas da Criminologia, com o objetivo de repensar a imaginação visível e invisível dos intelectuais e outros agentes que trabalham, direta ou indiretamente, com os limites imaginativos e discursivos dessa disciplina, questionando os motivos pelos quais tal 
área carece de uma nova criatividade do pensar humano para além do seu fechamento dogmático-positivo, na modernidade tardia.

Contudo, em que pese tais trabalhos estejam situados formalmente em diferentes áreas acadêmicas (história, sociologia e criminologia), nosso estudo explora justamente as semelhanças entre as perspectivas adotadas por esses autores, na medida em que não seria improvável afirmarmos que todos eles estão de acordo acerca da necessidade de trazer à tona ao caráter invisível dos mecanismos e das estruturas de poder consolidadas pelas instituições sociais por meio de um exercício genealógico, repensando as pegadas históricas deixadas pelo caminho das discussões que conectam tais disciplinas. Isso porque são eles (dispositivos de visibilidade/invisibilidade) que criam um imaginário de guerra para os Estados Soberanos, motivo pelo qual é imprescindível a tarefa de compreendermos não a "maldade" que está escondida na noite, nem o "bem" refletido pelo dia, mas questionarmos qual a realidade e quais os indivíduos que são protegidos, dia e noite, pelos mecanismos de luz e sombra.

\section{REPENSANDO A CRIMINOLOGIA PARA ALÉM DA CRIMINOLOGIA}

Comecemos nossas investigações pela análise dos limites e das definições tradicionais acerca da Criminologia: quais sejam, as histórias de seus discursos de poder e as suas possíveis contribuições políticas e/ou práticas no que tange à questão do crime e do controle social. Assim, enquanto disciplina ortodoxa, a Criminologia é marcada por tradições conflitantes, sendo ela entendida, de um lado, enquanto um campo "independente" que procura estabelecer os seus próprios objetivos, métodos de pesquisa e narrativas; e, de outro, intelectuais poderão ainda imaginá-la de forma tanto crítica quanto dialogada, em comunicação constante com outras áreas do conhecimento (GARLAND, 2009, 120). Em outros termos, essa acepção conceitual dual diz respeito ao número de análises que é possível desde os vieses contemplados nessa disciplina, podendo ela ser uma perspectiva integrada com perspectivas ou ser linha 
mestra, de forma isolada. Independentemente da definição de escopo, o que cabe é refletir até que ponto temáticas consideradas adjacentes ou acidentais às discussões criminológicas (crimes praticados pelos Estados Soberanos e pelos Mercados Globais) devem estar abarcadas pela Criminologia moderna.

Se compreendermos que o objeto político e/ou prático da Criminologia é a lei penal, as análises criminológicas seriam uma crítica complementar ao Direito Penal e ao sistema da justiça criminal, sendo a Criminologia apenas auxiliar, atuando como um marca-texto dos dispositivos jurídicopenais e de sua lógica. Caso em que estaríamos entendendo-a como subordinada aos discursos oficiais de dominação social pelas leis impostas pelas instituições de controle. Nesses termos, que liberdade tem a Criminologia para projetar-se como uma crítica para além dessas agências estatais e não estatais? Em outra ótica, como a área poderia se afastar da própria compreensão enfatizada pelo sistema de justiça, se seu logos estiver somente limitado pelo aspecto positivista dos Estados Soberanos? Quais os perigos decorrentes da edificação de uma imagem criminológica que serve a essa lógica de guerra hobbesiana dos Estados modernos, como adverte Morrison (2014a, p. 224 e ss.; 238-239)?

Como lembra Young, não podemos esquecer que a "expansão acadêmica da Criminologia” teve inúmeros fatores que, ao mesmo tempo, alteraram - e continuam alterando - o seu núcleo de pesquisa (a exemplo das análises recorrentes da sociologia e da psicanálise em seu campo de estudo). Ademais, foram responsáveis pelo desenvolvimento de sua esfera científica. Entre esses eventos, a ampliação e as diversificações do sistema da justiça criminal, e a migração, ao longo do tempo, de "estudantes da ciência política/administrativa" para o campo criminológico fez com que esses alunos pudessem ter acesso às políticas governamentais e à lógica disseminada no sistema de justiça. Paralelamente, o exemplo americano da "guerra ao crime" e, posteriormente, a "guerra às drogas" e a "guerra ao terrorismo", relativizaram os estudos positivistas da Criminologia, em nome de respostas mais práticas e aproximadas da sociedade (YOUNG, 2011, p. 32 e ss.).

Por outro lado, uma visão apenas legalista da Criminologia, no sentido de ela somente ter validade ou importância para os estudos 
jurídico-penais, permite que o problema da violência seja desconectado de uma determinada realidade sociocultural, da mesma forma que seria limitada pelos marcos do princípio da legalidade penal, podendo avaliar apenas os crimes definidos por lei. Para Bergalli, se os crimes que devem ser relevantes para a Criminologia forem, exclusivamente, aqueles definidos pelo Direito Penal, qual autonomia aquela teria sobre essa e qual Criminologia ou, inversamente, qual dogmática penal devemos procurar investigar (BERGALLI, et al., 2014, p. 209-210)?3 Além disso, uma imagem criminológica fora do contexto de uma sociologia do desvio (BECKER, 1963) implicaria entender de forma simplista o tecido social, a partir de uma lógica binária do permitido e do proibido, do certo ou do errado. Poderia também implicar uma percepção voltada às políticas de penalização ou (des)penalização, sem que, com isso, tenhamos condições de visualizar a "abertura paradoxal da lei moderna" (MORRISON, 2016, p. 290) e as contínuas mudanças e desafios dos "processos sociais" (GARLAND, 2009, p. 119).

De fato, se é normal que a sociedade seja estruturada por meio de normas formais e informais, não é menos verdade (ou normal) que, ocasionalmente, elas sejam quebradas por determinados sujeitos. Em contrapartida, a reflexão em torno dessa premissa não é tanto por que uma determina ordem social estabeleceu uma visão do justo ou do injusto para que pudesse se organizar socialmente, mas qual o mérito ou o interesse de determinados grupos e subgrupos que, em razão de terem ganhado a disputa política pela interpretação dos costumes sociais, se veem então autorizadas a subjulgar outros setores, tidos como excluídos ou marginalizados do ambiente social, por terem perdido a corrida política (BECKER, 1963, p. 1-2; 8 e ss.; 16 e ss.).

Os mecanismos de luz e sombra dos Estados Soberanos (as leis) escondem no imaginário criminológico essa realidade social/política, a qual chancela e diminui tal variação das sociedades, em prol de uma verticalidade total ou de uma obediência ao discurso técnico-científico, transformando esses dispositivos, não raras vezes, em uma pretensão de verdade do mundo social por meio da linguagem jurídica. Dessa forma, o que está em jogo, segundo Morrison, é a complexa funcionalidade da lei moderna, a qual procura propor um "sistema de classificação" 
social através de uma verdade jurídica que, ao descrever a sociedade em razão de um corpus positivo e estático, passa a criar um "processo de formalização", redutor das múltiplas constituições sociais, sujeito a qualquer tipo de manipulação e obscuridade, em vantagem do indivíduo que está interessado em criar "novas verdades sociais" (MORRISON, 2016, p. 290 e ss.). Isso porque as técnicas da lei moderna são sempre capazes de descrever parte da vida social e nunca o todo (DURKHEIM, 2016, p. 71 e ss., grifo nosso), como querem acreditar os defensores da "ciência pura" do Direito (KELSEN, 2006, p. 63 e ss.; 67, grifo nosso).

No entanto, se o imaginário criminológico for composto somente de análises sociológicas, estaremos diante de um novo - ou talvez já ultrapassado - fechamento dogmático da Criminologia, haja vista que ela passaria a ser um somatório quantificado de números, organizáveis ou não, dentro de determinados critérios. Poderia também ser entendida, na melhor das hipóteses, como nada mais do que uma sociologia do desvio. Nesse sentido, se até mesmo a sociologia encontra dificuldades para se estabelecer para além das respostas usuais, baseadas em um "fetichismo" metodológico de suas teorias e revisões clássicas e numéricas, resultado de uma idealização ou "imaginação sociológica" pouco criativa e pretensiosamente elitista, devido ao desejo dos sociólogos de se separarem dos economistas, dos cientistas sociais e outros especialistas (MILLS, 1959, p. 35-40), é preciso encontrar explicações do por que a Criminologia apresenta-se, nos tempos contemporâneos, como uma ciência também tediosa, burocratizada e estagnada em temas comercialmente rentáveis, uma singela Criminologia Administrativa ou de gestão de dados e teorias (YOUNG, 2011, p. 36; 83; 223 e ss.).

De acordo com Young, se o que resta à Criminologia e sua imaginação for a construção ortodoxa de fórmulas matemáticas e teóricas da ciência política ou da sociologia, então a Criminologia nunca será nada mais do que uma "ciência pobre", pois o que deve importar aos criminólogos em seu campo de pesquisa é também a possibilidade criativa de rompimento proposital com as demarcações epistemológicas daquilo que já é costume da Criminologia estudar (os crimes praticados pelos menos poderosos). Segundo o autor, é necessário honrar um campo de análise que nos permita trabalhar em um setor que tem por missão o estudo das tensões da justiça, 
existentes na ordem social e para além dela (YOUNG, 2011, p. 10 e ss.; 224-225). A fim de que a Criminologia possa, então, ser realmente crítica, é fundamental abster-se da singela repetição ou adequação ao que lhe é esperada, enquanto método, funcionalidade e objetivo, uma vez que o serviço dos criminólogos, diferentes da tarefa dos "robôs alegres" (YOUNG, 2011, p. 224, grifo nosso), não é demarcado pela aceitação dos discursos oficiais das agências de controle, mas pela constante oposição, resistência e uma natural desconfiança a ser desenvolvida, nessa linha de estudo.

Dito de outro modo, o que é urgente na modernidade tardia e na compreensão desses novos tempos de incertezas de posições e atuações sociais, e, especialmente, diante da cultura de consumo, é a emergência de uma nova Criminologia, não somente crítica no nome, mas baseada no comprometimento de realizar uma crítica avançada e nada tradicional nesse tópico de pesquisa (YOUNG, 2011, p. 224-225). Dessa forma, como explica Morrison em relação a essas novas perplexidades da imaginação criminológica global, a Criminologia encontra-se em um momento propício para desvelar seus erros teóricos e práticos, cometidos ao longo da história. No cenário hipotético da Criminologia, vemos, de modo geral, intelectuais acomodados e "pretensiosos" ou, ainda, um campo afundado em populismos penais que impedem o seu diálogo com as agências de controle e o resto da sociedade. Assim, o que há é uma verdadeira "Criminologia popular" (MORRISON, 2014a, p. 237-239) nos "pontos de ônibus", no trabalho diário e em todos os aspectos da vida coletiva (YOUNG, 2011, p. 83). Fato esse que faz com que ela precise tornar-se menos uma "fraude", no sentido de buscar alternativas globais para compreender os crimes sobre os quais realmente deveria trazer luz (MORRISON, 2014a, p. 240 e ss.).

Em razão desses crimes ocultados pelos dispositivos de luz e sombra dos Estados Soberanos na modernidade, é fundamental à Criminologia iluminar o que tem sido obscurecido pelo controle panóptico e racional do progresso, ao custo de vidas humanas. Nesse sentido, tal discussão não é apenas política ou ideológica, do ponto de vista da legitimidade ou da briga intelectual interna nesse campo de pesquisa; pelo contrário, independentemente da nomenclatura dada a esses crimes (genocídios, crimes massivos, internacionais, transnacionais, supranacionais, massacres 
extremos, crimes contra a humanidade, etc.), todos eles têm em comum a característica de serem praticados pelos mais poderosos, isto é, pelos Estados Nacionais e pelos Mercados Globais, que possuem os meios mais efetivos, bem como a grande maioria dos recursos disponíveis para o encobrimento de suas ações. ${ }^{4}$

Em recente tese, Gregg Barak descreve que muitos danos globais ocorrem devido às políticas neoliberais alimentadas pelo sistema capitalista e pelas agências supranacionais, pois essas, conjuntamente com os Estados-nação, são responsáveis pela formação de estratégias para a promoção e manutenção da miséria social, dos danos ao meio ambiente e de violações aos direitos humanos, em nome do aumento do lucro financeiro, e de suas receitas. Ao passo que as "corporações globais" têm ultrapassado economicamente o poder soberano das agências de controle oficiais, as grandes empresas multinacionais têm conseguido reunir as condições viáveis para impactar a forma de governar interna de determinados territórios, especialmente nos países subdesenvolvidos, em que o acesso aos bens de subsistência humana é escasso (BARAK, 2017, p. 3 e ss.; $42 ; 55 ; 119$ e ss.). ${ }^{5}$

Todavia, como lembram Dardot e Laval, não há nenhum motivo para nos surpreendermos com essa proximidade entre os atores supranacionais e os Estados Soberanos, haja vista a existência de uma verdadeira "parceria público-privada" entre eles, na qual a noção liberal de que o Mercado é mais ágil, sem a intervenção do Estado, é uma orientação deliberadamente equivocada e ingênua, produzida não por políticas econômicas (neoliberais), derivadas do sistema capitalista; senão pelo neoliberalismo, uma nova forma de governar os sujeitos "empreendedores", a partir de uma racionalidade capaz de fazer do mundo a sua "razão", mundo de existência, bem como tem por função guiar a vida social não pela restrição, mas pela "liberdade" (DARDOT; LAVAL, 2016, p. 16-19; $28-31 ; 277-283 ; 329-350){ }^{6}$

Como consequência desse quadro, como constata Friedrichs, os crimes praticados por essas corporações (crime of powerful) têm escapado do sistema de justiça porque são repreendidos de forma "desproporcional" quando comparados aos crimes comuns (street crimes), punidos pelo sistema penal em maior escala. Ademais, explica: a criminologia 
administrativa continua a insistir nessa visão convencional de punir "os fracos", alvo central dos discursos midiáticos que projetam a criminalidade em um setor específico da sociedade (FRIEDRICHS, 2015, p. 40 e ss.).

Conforme alerta Bernal Sarmiento (et al., 2014, p. 68 e ss.), se desejamos oferecer, com a Criminologia, uma resistência para que esses eventos obscurecidos pelos Estados Soberanos não voltem a ocorrer (genocídios, crimes em massa, entre outros), precisamos utilizar a categoria política da memória, de modo a desvendar os ditos "mistérios" dessas parcerias público-privadas, responsáveis pelos mais horrendos processos de violência estrutural na história da humanidade, cometidos contra aqueles que são tidos como "os danos colaterais", o sangue menos civilizado e, portanto, descartável para o "progresso" técnico-científico da felicidade terrena.

No entanto, tal linha teórica não deve ser compreendida como um pessimismo ocasional que justificaria a possibilidade de descartarmos, por completo, a noção de progresso na modernidade, mas, seguindo a orientação de Mate, pouco adianta a negação como exercício de simples inconformidade ou, inversamente, a aceitação mecânica daquilo que nos beneficia. É necessário "organizar o pessimismo”, de modo a reiterar uma posição contrária ao que de pior existe como fundamento desse progresso: o seu "esquecimento"; "um progresso entendido dogmaticamente" e que confunde "a marcha da história com a evolução da natureza". 0 papel da memória perpassa, assim, a possibilidade messiânica de desconstrução das injustiças passadas (manter "vivo" o sofrimento dos oprimidos), pois nenhuma justiça pode ser edificada, segundo Mate em relação às teses benjaminianas, sem a interrupção da "continuidade histórica" de destruição da "ideologia dos vencedores"; o passado não deve "dar razão ao presente", mas o presente necessita "andar na contramão" do que ainda não conhecemos (MATE, 2011, p. 25-29; 52; 118-122; 260 e ss.; 276-277).

Entre essas histórias ainda não descobertas e invisíveis aos olhos do civilizado, ${ }^{7}$ Morrison se esforça para demonstrar - a partir de uma narrativa desconstrutiva - alguns dos fatos apagados pela principal história do progresso vitorioso. Como exemplo, mencionamos o evento conhecido como 11 de setembro de 2001 (o ataque as Torres Gêmeas). Ele não foi um momento de exceção ou de rompimento da perspectiva histórica 
narrada pelos civilizados, como acreditou a mídia nacional (americana) e internacional. Em verdade, o discurso de guerra e de ameaça bélica do ex-presidente Bush, nesse período, apenas evidenciou a antiga reprodução da lógica de guerra (hobbesiana), instrumentalizada pela noção de poder soberano, que indica a necessidade de que se tenha a centralidade de uma figura, como ocorre, por exemplo, com a imagem de um Rei: para que este tenha condições de se manter existindo, e governando a ordem social, é necessário que ele seja peça central de um sistema de governança. Essa linguagem continua a existir no modus de vida e de afirmar vida sobre o outro (morte), na modernidade.

Nessa perspectiva, o Leviatã de Hobbes simboliza não somente "a condição natural" da sociedade moderna, mas o projeto de construção de um "espaço civilizado" e racional, no qual o medo dos indivíduos de morrer pela guerra passional contra si, isto é, em face da necessidade de terem suas tendências autodestrutivas apaziguadas pela noção contratualista hobbesiana, os súditos precisam sempre jurar sua total fidelidade ao Soberano. Assim, ao passo que os homens entregavam sua fé e liberdade ao Rei (Estado), este lhes cerceava. Nessa configuração, temos uma entidade conhecida como extensão divina e/ou terrena de alguém hierarquicamente superior, que pode julgar e controlar, pois detém o poder de veto ou de permissão. Assim sendo, no jogo em troca de tal submissão os fiéis desse regime estatal recebiam a proteção comunitária e racionalizante do Soberano, tendo ele inclusive a legitimidade para impor a guerra, por meio de sua espada militar e de seu cetro mítico (poder e fé), aos inimigos externos que pudessem vir a ameaçar esse projeto de espaço civilizatório (MORRISON, 2012, p. 4-5; 16 e ss.; 18-20; 27 e ss.).

Por esse motivo, uma ameaça ao World Trade Center, complexo empresarial atacado por fundamentalistas islâmicos (discurso oficial americano e midiático), não era uma ofensiva contra um mero edifício, aleatoriamente desenhado, mas uma ação imperdoável praticada contra o símbolo que mais bem representava o Leviatã de Hobbes (MORRISON, 2012, p. 22 e ss.). Ironicamente, se Bush buscou eliminar inimigos externos que ofenderam a lógica do progresso humanístico, pois era guardião das fronteiras civilizadas de seu território nacional, Bin Laden serviu a esse papel não como "terrorista” (adversário aleatório), mas como alguém 
incivilizado que colocava em risco, segundo a lógica bélica americana, os ideais dessa sociedade. Todavia, independentemente de que tenha ou não Bin Laden cometido tal investida contra a hegemonia americana, ele poderia ter utilizado essa mesma lógica de guerra hobbesiana para fundamentar suas ações: atacando os "seus" inimigos externos, estava propondo uma contraofensiva aos americanos.

O escalonamento dessa lógica de guerra, nada mais é do que uma consequência natural, porém difícil de enxergar, das bases teóricas não tão limpas e instrumentalizadas pela mão suja dos dominadores que, dado o temor de seus mecanismos, afastam os impuros pela preservação de um determinado estilo de vida ocidental e branco sobre aquele que possa vir a projetar determinadas características atávicas. Como exemplo, mencionamos o sucesso do pensamento da Antropologia Criminal da Escola Positiva Italiana, ${ }^{8}$ tanto no setor acadêmico quanto social, durante o século XIX, que justificou a lógica de guerra e a escondeu em um discurso científico e pouco visível, convertido em uma promessa de curar esse incômodo evolutivo da humanidade, os incivilizados (bárbaros, primitivos, não evoluídos diante dos padrões europeus, etc.).

Em contrapartida, como lembra Zaffaroni, o 11 de setembro serviu para o ex-presidente Bush como um pretexto para lançar o poder soberano do Estado Moderno americano contra o outro (irracional), motivo pelo qual essa administração pode expressar dois fatos: que a lógica de guerra de Hobbes jamais havia sido extinta (pelo contrário, foi necessário reforçála) e que tal evento, devido a seus escalonamentos, testou os limites tradicionais entre o espaço interno e externo, geograficamente demarcado, a tal ponto extremo, que esses "limites" desapareceram, pois o local e o global se misturaram entre si, em detrimento de milhares de vidas perdidas e tidas como acidentais (ZAFARRONI, 2013, p. 168; 169 e ss.; 175).

Se a Criminologia tem algum outro papel relevante na transformação do pensamento social, do ponto de vista da Democracia, não é possível que sua missão seja fruto de um estado provisório ou momentâneo de descontentamento (pessimismo passageiro), em face da dificuldade em consolidarmos essa categoria política, tão relevante e pouco estável, nos quadros dos tecidos das sociedades - e especialmente no caso do contexto social brasileiro -, como costume ou prática social. É o oposto. 
Deve a Criminologia alertar sobre os processos históricos de opressão massiva contra os incivilizados, em termos de Teoria Crítica e Política, no sentido de revelar a outra face dos pressupostos daquilo que constitui, fundamentalmente, sua lógica de atuação (as leis ou o Direito), devendo lutar contra os excessos do progresso desmedido, baseado na concepção de felicidade eterna, no plano terrestre.

Do contrário, se a Criminologia não está atenta a essas incongruências da modernidade, passa a predominar na imaginação dos criminólogos (criminológica) um movimento de naturalização psíquica e racional, voltado ao entendimento de que os regimes totalitários ou as práticas genocidas dos Estados Soberanos e dos Mercados Globais foram eventos de exceção, termo esse que sugeriria algo aparentemente improvável de que voltasse a acontecer, pois se trataria de um passado histórico já esquecido ou superado. No entanto, o efeito causado por tal expressão é outro, uma vez que simboliza a tentativa de incorporação de um fato normal e já naturalizado no modo de ser ocidental.

Sobre a tarefa de (re)memoração da Criminologia, não apenas o ataque às Torres Gêmeas, mas também no caso Auschwitz encontra-se um profundo "catalisador de uma determinada forma de fazer política" na modernidade, segundo Mate, uma vez que contestar o Holocausto é uma tentativa de nos opormos a esse efeito normalizador de realizar o que politicamente já é tido como "correto" na linguagem do progresso técnico-científico, viabilizado pelos seus mecanismos racionais (de luz e sombra), bem como são situações de teste da própria "racionalidade do presente" (MATE, 2006, p. 15). Se a Criminologia precisa ter um papel político na sociedade, esse exercício rememorativo é primordial para o seu desenvolvimento teórico e crítico, enquanto local de estudo e de pesquisa.

Mesmo Bourdieu, com seu pensar sociológico, muito embora tenha tratado da importância do Estado como organizador da vida social, por meio do Direito como racionalidade superior (2014, p. 250 e ss.), não estava alheio ou cego aos processos "unilaterais" e perigosos da história e, por isso, colocou em relevo aos próprios sociólogos essa problemática (perigo), os "achismos" do senso comum ou as pronto crenças ("protocrença") históricas que impedem a desconstrução das 
doxas (verdades incontestáveis), sendo manipuladas pelos agentes sociais e pelas agências de controle como um verdadeiro "golpe de Estado".

Para Bourdieu:

[...] A história destrói os possíveis: o espaço dos possíveis não para de se fechar, a todo instante. [...] A história de uma instituição exitosa implica a amnésia da gênese da instituição, que a história elimina possíveis e os faz esquecer como possíveis, e que ela até mesmo torna impensáveis os possíveis. Há possíveis que são revogados de uma vez por todas, mais gravemente do que se fossem proibidos, pois os tornamos impensáveis. 0 que conhecemos como realidade história, centrais nucleares, ortografia, divisão entre história e geografia, existência da geologia etc., tudo isso aparece de tal forma que o contrário não é nem sequer excluído, mas impensável (BOURDIEU, 2014, p. 168, grifo nosso).

Essa linguagem redutora do sempre-foi-assim e jamais deve serde-outro-modo 9 elimina as possibilidades criativas de resgatar alguma realidade passada e de conceber algum fenômeno novo e contrário a uma ordem historicamente arbitrária. Isso ocorre porque, ao constituise como regente da vida social, ela passa a dispor e a impor uma série de mecanismos e estratégicas simbólicas que, por sua vez, procuram recobrir o discurso oficial estatal com uma aparência de naturalidade discursiva, devido ao tempo de maturação institucional que já possui essa, na qualidade de lógica autorizada (e de guerra). ${ }^{10}$

0 treinamento de procurar por essa invisibilidade conceitual e prática não é somente uma estratégia aconselhável ao sociólogo, mas ao filósofo que precisa construir uma teoria do conhecimento, na qual conhecer, segundo Mate, "é dispor de uma agudeza visual capaz de ver algo insólito em objetos, situações ou acontecimentos que todos vemos" (MATE, 2011, p. 22). Dessa forma, se a Criminologia e o imaginário de seus intelectuais necessitam se desenvolver, de maneira autônoma e integrativa - eis o desafio -, em relação às outras análises teóricas e/ou práticas (jurídica, sociológica, filosófica, antropológica, entre outras), pertence, portanto, aos criminólogos a provocação de organizar seu pensamento crítico, a fim de encontrar na experiência global dos sujeitos em claro "estado de exceção" (vencidos), (MATE, 2011, p. 188 e ss.), a aprendizagem de um novo progresso. 
Na modernidade, o criminológico precisa aprender a ser mais parecido com um "catador de desejos", procurando no lixo "tesouros" perdidos, isto é, buscando nos milhares de "oprimidos" que foram incinerados pelo progresso da máquina iluminista a real história obscurecida pela mão invisível do Estado e de outras agências supranacionais. 0 que dignifica o catador (e também o criminológico) é sua inconformidade natural, pois dela advém a esperança, perante um sistema de classificações que não tenha por finalidade "salvar o que a cultura descarta", bem como "descartar o que ela salva", haja vista que o "antídoto contra a miséria" está nos excluídos, pois somente eles têm condições de "imaginar um sistema sem exclusões", afirma Mate em relação à proposta benjaminiana (MATE, 2011, p. 39-40; 56 e ss.).

Imbuído desse espírito crítico, reconhece Bauman, que a "derrota da Alemanha nazista" e a implosão do comunismo russo não fizeram desaparecer os crimes contra a humanidade (genocídios). Intermináveis vidas humanas foram culpadas por serem vistas como tendo o tipo sanguíneo considerado não oficial. Outro julgamento era que tais pessoas estariam fora das zonas civilizadas, porque não faziam parte dos núcleos considerados de prestígio por aqueles que as desmereciam em nome da marcha acelerada do progresso.

Bauman ainda destaca que nenhum desses eventos e julgamentos históricos/políticos foi uma "invenção dos totalitarismos do século XX", mas sim que foi a inovação tecnológica trazida pelo progresso moderno que permitiu a contínua repercussão desse pensamento autoritário e de guerra. Além disso, nos dias atuais, essa lógica higienista do progresso não cessa de ser ampliada, moldando diversos aspectos da vida coletiva. Para o autor, existe então um novo animus ou energia, que procura fundamentar o discurso da ideologia dos vencedores, isto é, a crença na "elegância do Grande Projeto". Assegurado pela crueldade humana, deixa de ser um exemplo distante ou imaginário, para tornar-se hiperreal, uma arquitetura idealizada "para durar mil anos ou a eternidade". Esse tratado de difícil percepção encarregava-se de "matar como modo de forçar a realidade social a corresponder" ao novo estilo ou modo de vida ocidental. De acordo com o autor, esse mantra moderno dos Estados Soberanos representa a fórmula de jardinagem de certas plantas que 
precisam ser eliminadas, pois se apresentam como "ervas daninhas": se "podemos fazer e (então) vamos fazer", precisamos "remodelar a condição humana" (BAUMAN, 2010, p. 77-78).

De qualquer sorte, quando tratamos dos limites epistemológicos e políticos da Criminologia, de seu imaginário e da sua tarefa de pesquisa sobre os genocídios, não podemos entender esses crimes como alguma coisa, segundo Zaffaroni, que acontece "do dia para a noite", sem nenhum aviso. Isso porque são "processos de preparação", levados a cabo por meio de "técnicas de neutralização" e de discursos populistas de indiferença social, a exemplo da "negação da responsabilidade, negação dos danos, negação da vítima", entre outras narrativas (ZAFFARONI, 2014, p. 218-219). ${ }^{11}$

Em virtude da urgência de estudos sobre crimes massivos e suas múltiplas possibilidades teóricas e/ou práticas de análise, para a Criminologia, tais crimes internacionais, segundo Zaffaroni, apontam para o fim da antiga divisão entre "Criminologia teórica e prática", haja vista que esses novos temas devem ser capazes de formar uma "Criminologia prática [política] com base teórica", uma vez que possa estar preocupada em prevenir esses crimes contra a humanidade (ZAFFARONI, 2014, p. 214-215).

De fato, não é a Criminologia que está em dívida ou a serviço de determinadas "visões" ou imaginários criminológicos (Criminologia Crítica, Sociologia do crime, Criminologia voltada a proferir conselhos políticos, etc.), no sentido de possuir um único e específico objetivo de pesquisa, em decorrência da corrente do pensamento intelectual (criminológico) que possa a vir a pertencer. É o oposto. Segundo Garland (2009, p. 117 e ss.; 119-120), "não há razão alguma" para que a Criminologia seja percebida como um saber subordinado ao sistema de justiça criminal, em vez de voltar-se a dimensões para além dele.

Por outro lado, em virtude de um novo interesse de pesquisa (crimes massivos), as tensões entre a política e a prática, dentro do espaço de disputa da Criminologia, foi eliminado, a partir das reflexões de Zaffaroni; o que acontecerá com a Criminologia, hipoteticamente, quando surgir um problema mais urgente de pesquisa que os genocídios e, por isso, a imagem criminológica poderá estar tão rompida, epistemologicamente, que desejaremos voltar a essa distinção (política e prática) ${ }^{12} \mathrm{Ou}$, ainda, 
em outro cenário, se não há mais divisão entre a política e a prática, a Criminologia que é possível apresentar na universidade tem o mesmo fundamento, comparada àquela concebida pelo agente que trabalha para as instituições de controle? Se a resposta for afirmativa, diante desse segundo questionamento, então estaremos admitindo que os interesses do sistema de justiça e das instituições oficiais de controle são iguais ou similares àqueles protagonizados pelos intelectuais, nos centros de ensino. Definitivamente, não é e nem pode ser viável essa hipótese, se a Criminologia for, de fato, crítica.

Como saída a esse impasse, Garland (2009, p. 119 e ss.) sugere que a Criminologia precisa buscar uma "solução dialogada" com outras áreas do conhecimento, bem como com distintos setores institucionais e burocráticos da sociedade. Porém, não pode, em face dessa comunicação política, comprometer totalmente as teorias que diferenciam as distintas linguagens da vida social (Criminologia e senso comum, por exemplo). Em contrapartida, não é menos verdade, adverte Riveira Beiras, que os moldes tradicionais de se pensar a Criminologia, reproduzidos nas universidades, precisam alcançar novos ares. Ocorre que, em razão dos novos temas globais, será que eles devem ser analisados nos tradicionais estudos penais? Nesse cenário eles estariam nos "novos estudos em Criminologia"? Ou há a necessidade "de algo mais" ou de algo "diferente" da "Criminologia"? (RIVEIRA BEIRAS, 2014, p. 214).

Podemos pensar que esses questionamentos também perpassam o alerta feito por Morrison quando defende a necessidade de construção de algo real, que nunca existiu na história da Criminologia, um "apartheid criminológico" ("consciência global"), uma inovadora ação política de resistência à lógica de guerra hobbesiana, especialmente tendo em vista a passividade dos intelectuais que jamais se ocuparam de oferecer uma barreira à linguagem civilizadora do progresso racionalizante (MORRISON, 2012, p. 2-4; 58 e ss.; 76 e ss., grifo nosso).

Em apertada síntese, se, por um lado, uma Criminologia teórica e desconectada da realidade prática pode implicar construções abstratas ou ideológicas que não condizem com os reais massacres que estão sendo praticados contra boa parte da humanidade; por outro lado, uma Criminologia prática, sem base teórica, está mais próxima de prontas 
crenças institucionalizadas como fatores normais, pelas instituições oficiais, frente às sociedades, bem como incorre no evidente perigo de dar voz a populismos penais, em vez de incentivar uma construção argumentativa e racional, que deve fornecer nova perspectiva sobre uma mesma problemática comum de toda a vida social: a violência.

Todavia, em uma Criminologia política de cunho teórico, apesar de parecer ideal, pois traduz os problemas "reais" da sociedade em uma linguagem científica, há sempre a possibilidade de que o conhecimento das realidades leve ao realismo, como disse Bourdieu (1983, p. 75). Nesse sentido, o criminólogo não pode estar subordinado à área de pesquisa, cego à lei penal e ao sistema da justiça criminal. Tem de perceber quais prontas crenças ou "protocrença" (BOURDIEU, 2014, p. 168) fazem parte de sua imaginação criminológica e, por isso, devem ser iluminadas por uma crítica criminológica realmente reflexiva. Isso significa dizer que aquele que tem acesso aos produtos gerados tem de (re)pensar criativamente o que o crimonólogo está ou pode estar deixando de narrar nessa área de pesquisa.

É evidente que o criminólogo jamais poderá narrar tudo que desconhece, pois sempre lhe faltará capacidade científica acerca do que deveria ou poderia ter conhecimento a respeito. No entanto, é fundamental evitarmos o total desconhecimento dos problemas sociais, em prol de formulações excessivamente positivistas, enquanto método e conteúdo, haja vista que essas narrativas racionalizantes fazem parte dos mecanismos de luz e sombra, utilizados de forma obscurecida para a prática de crimes massivos cometidos pelos Estados Soberanos e pelos Mercados Globais, encobertos pelo manto da legalidade dita democrática, dessas instâncias de controle.

Em uma Criminologia teórica de cunho prático talvez se esteja diante da pior das alternativas, haja vista que essa perspectiva faz da imaginação criminológica (científica), uma redução volátil dos mais variados problemas da ordem social. Entre excessos de abstrações e de teorias, e de ampliações puramente práticas/sociais, o que nos parece plausível esperar da Criminologia é uma solução dialogada com outras áreas do conhecimento. Muito embora não esteja claro se a Criminologia que estuda os crimes genocidas praticados pelos Estados Soberanos e pelos 
Mercados Globais deve ter uma nova etiqueta, isto é, se esse novo estudo deverá ou não ser nomeado por uma nova Escola Criminológica; o que nos parece urgente, independentemente dessa discussão é o emergente e necessário desenvolvimento discursivo e criativo na Criminologia moderna, a ponto de virar a Criminologia contra si própria, pô-la contra a parede intelectual e prática, testando seus limites e imaginações criminológicas.

Na sequência, passamos a estudar o complexo dilema dos Estados Soberanos na modernidade, que, embora tenham suas lógicas racionalizantes (de luz e sombra) flexibilizadas por diversos fenômenos pertencentes à marcha do progresso e, com isso, parecem não mais conseguir projetar uma identidade segura aos indivíduos aos quais juraram suportar e proteger, é primordial que organizem a vida social, pois nenhuma sociedade pode estruturar-se sem normas culturalmente determinadas por uma linguagem da ordem da tradição e da coerção. De forma provocativa, partimos desde já do seguinte questionamento: até que ponto o Direito como instrumento de dominação de instituições sociais como o Estado não acaba por dominar de forma tão excessivamente esplêndida, que é capaz de esconder com facilidade o outro lado de sua lógica de guerra (soberana), a possibilidade de morte e de destruição de parte da humanidade, social e juridicamente destituída?

\section{DE QUE MODO OS ESTADOS-NAÇÃO ESTRUTURAM A ORDEM SOCIAL NA MODERNIDADE? ${ }^{13}$}

Tanto os Estados Soberanos quanto os Mercados Globais são capazes, na contemporaneidade, de propor agendas político/sociais, em diversos aspectos de nossas vidas. Os processos naturais de organização da ordem social implementados pela via jurídica, como linguagem do Estado, tem perdido cada vez mais eficácia, diante de um tempo de incoerência e incerteza das posições sociais, frente às demandas populistas e aos novos fenômenos característicos da modernidade tardia. Como consequência desse quadro, à medida que a distância de valor entre os indivíduos e as instituições sociais aumenta, mais evidências apontam para o que seria uma crise de sentido e de falta de confiança nas agências de controle, 
que deveriam nos proteger contra os danos sociais massivos, causados por essas instâncias (Estados, Mercados, etc.) que já estão, diria Young (2007, p. 2-3; 6), deterioradas e desgastadas em um tempo de constante ruptura e descontinuidade individual/social.

De forma exemplificada, no plano teórico ou moderno (ou para aqueles que entendem que estamos em uma modernidade tardia), essas instituições ou "fatos sociais" (família, trabalho, casamento, Estado) deveriam ser hábeis o suficiente (naturais e coercitivas), no sentido de nos proporcionar identidades seguras e firmes, dentro dos tecidos sociais (DURKHEIM, 2007, p. 10 e ss.; 13; 124-125). Isso porque, tendo elas a finalidade/função de evitar situações de profunda "anomia", ao regrarem a estrutura social por meio de um conjunto de crenças ou normas, como advertiu Durkheim (2014, p. 235 e ss.), era necessário investir o máximo possível nesses estatutos essenciais, de forma a diminuir as chances de nos sentirmos perdidos ou de fugirmos dessa sensação perigosa de um vazio institucional/social e outros sentimentos de alienação, tais como o tédio, a perda de sentido/objetivos, o suicídio, a autodestruição e outras formas de demonstração da ausência de narrativa institucional, que possamos vir a experimentar.

Por outro lado, as fronteiras entre o local e global da modernidade foram transpostas a tal ponto, que a nova norma individual/social é não ter norma (não norma, um sentimento de ausência normativa). Fato esse que seria um acontecimento quase impensável por Durkheim e outros autores, de diversas áreas conhecimento, naquele período. Nesse sentido, o logos da sociedade moderna não é a firmeza dos conceitos técnico-científicos, mas a permanente sensação de uma melancolia institucional, haja vista que os limites entre o real e o virtual são testados com tanta facilidade que novos espaços sociais de disputa são desenvolvidos para incentivar não o controle, mas o descontrole social. ${ }^{14}$

A procura por inovadoras narrativas subjetivas nessa modernidade é apresentada, enquanto um novo quadro ou fato social de um tempo de difícil descrição. Assim sendo, algumas proposições são interessantes de serem apontadas: Como classificar com precisão um momento histórico-cultural impreciso por definição? Quais crimes e sujeitos devem ser objeto de estudo da Criminologia? Como explicar um imaginário criminológico que, 
apesar de apostar em métodos positivistas, está cego para os processos modernos da vida social? De que forma podemos dividir o trabalho social (DURKHEIM, 2016, p. 62 e ss.; 67-70; 74; 84), a partir do fortalecimento de "vínculos de solidariedade", reforçados pelo Direito (civil e penal), quando essa lógica jurídica está não apenas deteriorada, mas que em vez de nos dominar, domina tão excessivamente e de maneira tão exemplar, que sua linguagem imprecisa torna-se, ainda assim, uma forte expressão de vida e de morte, fundamentada pela noção de soberania, como disse Mbembe (2011, p. 19 e ss.)? Em que sentido podemos efetivar uma Democracia material, no plano dos costumes ou práticas sociais e não somente no estatuto legislativo ou ideológico brasileiro, quando a Democracia que temos atualmente está contaminada por slogans populistas? ${ }^{15} \mathrm{E}$, finalmente, de que modo identificar e explicar os mecanismos de luz e sombra dos Estados Soberanos e das agências supranacionais, que não medem esforços para manipular nossas emoções na modernidade?

Longe de termos respostas finais a essas perguntas, destacamos que até mesmo Morrison demonstra dificuldades em descrever as recentes dinâmicas e o humor "dos intelectuais", na pós-modernidade. Para o autor, poderíamos abordar a modernidade sob uma perspectiva "alegre" ou acomodada, haja vista que a vida no Ocidente não parece estar tão ruim quanto se imagina, pois nunca antes "apreciamos e tivemos tantas mercadorias e oportunidades", como temos neste período histórico. Por outro lado, do ponto de vista "melancólico", presenciamos também a falta de energia ou motivação social para continuarmos a acreditar nos velhos e, ao que parece, ultrapassados projetos: "liberalismo, socialismo, comunismo, democracia radical, nacionalismo nos países de terceiro mundo", entre outros (MORRISON, 1995, p. 1).

Todavia, em um tom mais "depressivo", Morrison explica que as coisas estão péssimas para muitas pessoas no Ocidente, em relação ao "recorde" de sujeitos que vão ao psiquiatra e que precisam de consulta, de drogas controladas e de tratamentos para suportarem suas rotinas diárias. Não é menos verdade que a AIDS e o abuso de drogas têm gerado desemprego e arruinado incontáveis vidas humanas. Ademais, há um "crescimento industrial" significativo de construção de prisões e de utilização de segurança privada. Além disso, continua, estamos imersos 
em uma cultura altamente estilizada que nos diz quando e como devemos temer "os crimes de rua", imagens, artigos e outros meios fazem parte dessa invisibilidade intencional, ocultando à sociedade e ao sistema de justiça os crimes praticados pelos poderosos. Nesses termos, poderíamos indagar: "onde o mundo real começa e o espetáculo termina?... O que é real e o que é imaginação?" (MORRISON, 1995, p. 2 e ss.).

De acordo com Morrison, necessitamos desesperadamente de novos critérios para diferenciar determinados "tipos de informação, de conhecimento e de percepções", bem como eles precisarão ser importantes o suficiente para ir além das "emoções ocasionais" e serem, significativamente firmes, para determinarem o que pode ou não ser crime e quem pode ou não ser criminoso (MORRISON, 1995, p. 2). Em contrapartida, como lembram Hillyard e Tombs, durante esse processo de classificação dos ditos crimes e criminosos, existe sempre a falsa impressão de que há uma "realidade ontológica" e imutável, construída por meio dessas categorias imaginárias. No entanto, "crimes e criminosos são eventos fictícios", pois precisam ser construídos antes do surgimento desses conceitos, apresentando-se, assim, como "mitos" já naturalizados em nosso convívio social (HILLYARD e TOMBS, 2004, p. 11 e ss.).

Assim sendo, se desejamos ir para além da Criminologia e de seus usuais métodos de abordagens, dizem Hillyard e Tombs, precisamos substituir a tradicional distinção entre crime e punição, a partir de um estudo acerca do dano social e das formas alternativas de compensação ("levar a sério esses danos"), de modo a nos afastar de uma "Criminologia Crítica" que estuda apenas as definições positivas, desde 1930 em diante, e elencadas pelo sistema de justiça criminal, edificando no imaginário criminológico somente as causas ou os fatores econômicos e sociais para a criminalidade (HILLYARD; TOMBS; GORDON, 2004, p. 9; 270 e ss.).

Em outra linha argumentativa, a violência estrutural ou "simbólica" do Estado (o Direito ou as leis) cumpre a função não apenas de organizar a vida social, a fim de forjar objetividades e subjetividades (BOURDIEU, 2014, p. 250), mas também cumpre a função de apaziguamento ou de controle das "pulsões naturais" de todo ser humano, como falava Freud (2010, p. 43 e ss.; 48-49). Essa lógica de dominação cumpre uma finalidade social coercitiva, não naquilo que pensava Durkheim como a naturalização 
de um fato pré-dado e construído socialmente de forma unilateral (DURKHEIM, 2007, p. 124 e ss.), mas no entendimento pela criação de uma "reciprocidade tácita" e tática (estratégica dos mecanismos de poder) entre os grupos que dominam e os que se submetem a essa dominação (BOURDIEU, 1997, p. 22). No entanto, quem é dominado dificilmente irá requisitar, de modo espontâneo, que uma lógica ou um mecanismo arbitrário (luz e sombra) lhe controle, do ponto de vista natural (mecânico, automático, etc.). Por esse motivo, todo processo de dominação exige um "habitus" (BOURDIEU, 2014, p. 78; 166), isto é, a naturalização de um discurso, de uma forma de pensar e de agir afirmada como um dado de realidade, naturalizado como inerente àquele tipo de sociedade, a exemplo do poder defasado, mas ainda presente na concepção de burocracia, no atual estatuto doutrinário da modernidade, em alguns países.

Para Durkheim (2007, p. 10 e ss.; 124-125), existe uma força naturalizante (uníssona), racional e necessária, do ponto de vista da fisiologia social, que faz os homens se curvarem perante as instituições sociais, fundamentada não na noção de uma "natureza [inerente ao] do indivíduo" hobbesiana, diz o autor, mas em uma base e razão coletiva, voltada ao estabelecimento de uma consciência moral ou coesa das sociedades. Destaque-se que, mesmo por motivos diversos (social, natural e/ou coercitivamente naturalizante), existe outra faceta dos mecanismos de luz e sombra dos Estados Soberanos (as leis) que escondem o outro lado do sentido do termo dominação, categoria jurídica que constrói um determinado imaginário criminológico sob o amparo de um moderno, racional e avançado conceito, o de soberania (poder).

Essa visão soberana de um Estado não diz respeito à habilidade ou não dessa instituição de conseguir reunir as condições essenciais ou para cumprir as leis locais de seu território - ou, pelo menos, não é apenas isso. É nesses termos que é tão problemática tal descrição, a partir de modelos de classificação distintos, porém relacionados entre si. Pelo contrário, a "expressão última da soberania" justifica-se pelo "poder e na capacidade" do Estado de decidir, segundo Mbembe, "quem deve viver e quem deve morrer". Essa é uma nova forma de fazer política, que dizima populações inteiras a "céu aberto", devido aos processos de colonização dessas "matanças invisíveis", inspirados na lógica de guerra/ 
vida/morte/forjadora de subjetividade e imposta por "múltiplos poderes" da modernidade tardia: "disciplinar, biopolítico e o necropolítico". Esse "Estado de sítio" permanente, segundo o autor, não possui ou não está interessado em desenvolver critérios para separar o inimigo interno do externo (MBEMBE, 2011, p. 19 e ss.; 52-53). Novamente, observemos que as fronteiras entre o local e o global ficaram menos visíveis e precisas, em uma perspectiva geográfica, filosófica, política, jurídica, criminológica, entre outras.

De fato, como esclarece Mate, a partir das teses benjaminianas, há uma violência (natural) que cria o Direito (física e subjetiva) e outra primordial a sua conservação (aquela estrutural e derivada da linguagem jurídica). Todavia, seguindo essa orientação, não devemos compreender os locais onde são praticados esses crimes massivos e impetrados contra os vencidos como algo que está "suspenso" temporariamente. Isso porque a marcha do progresso sobre parte específica e incivilizada da humanidade, no tempo moderno, nos adverte o seguinte: o "excepcional é a regra", pois a "tradição dos oprimidos nos ensina que o estado de exceção" é a norma (MATE, 2011, p. 188-190; 192). Viver nesse progresso que se esquece do seu lado fascista, mantém vivo o projeto civilizador e iluminista, que deseja iluminar o permanente momento de excessiva dominação, em que estamos a presenciar, nos dias atuais.

Num passado não tão distante, Weber (2010, p. 61 e ss.) afirmava que não há outra razão para o Estado atuar, senão a que implica no "cumprimento das leis" (racionais), porque nela está a linguagem jurídica, bem como toda a sua força física autorizada por esse poder (jurídico), que justamente mantém legítima essa estrutura. Porém, o que ocorre quando esse mecanismo técnico-científico de luz e sombra define quem pode ou não ser "sujeito de Direito" ou, ainda, em que situações a sua "política" é um "trabalho [classificativo] de morte" e de excesso de violência estrutural como um "direito de matar", isto é, uma instituição que não consegue funcionar, exceto em "Estado de emergência" (MBEMBE, 2011, p. 20-21). Com razão, Morrison parece estar descrente com essa realidade de espadas mortíferas quando se trata da forma de legitimar o Estado moderno por meio da lei, pois, ao que tudo indica, essa linguagem oficial "perdeu a sua racionalidade" (de existência) e, por isso, cabe indagarmos, de que modo 
conseguiremos continuar acreditando em um "padrão de coerência ou em um objetivo social comum" (MORRISON, 2016, p. 515-517)?

Sobre a mera aparência da universalidade de direitos que o progresso promete oficial e ilusoriamente a todos, conforme a interpretação de Mate, não devemos nos deixar enganar pela beleza de determinadas narrativas modernas (racionais) que juram pela democracia liberal, pelos direitos humanos, pelo Estado social e democrático de Direito, pela distribuição de renda e pela globalização. Isso porque elas marcam um "progresso" construído "às costas da humanidade", haja vista que "onde não há direito para alguns, ainda que fossem poucos", coloca-se em dúvida a crença na justiça do direito como um todo, isto é, na linguagem jurídica "suspensa pela vontade dos poderosos", produtora de mortos e de miséria (MATE, 2011, p. 11).

Embora os mecanismos de luz e sombra dos Estados Soberanos tenham sido edificados, ideologicamente, para suportar todos os estilos de vida possíveis, condicionando as grandes narrativas do progresso como condição permanente de uma possível melhora para toda a humanidade, na prática, a única narrativa (estilo) contemplada por essas estruturas objetivas foi aquela derivada do homem racional, que se alienou diante de uma modernidade secularizada e concebida dentro da promessa dos valores estáveis, pertencentes ao antigo e já ultrapassado modelo de sociedade. Isso porque fora edificado com base na sociedade industrial.

De forma emblemática, a noção de Estado moderno só poderia ter conseguido constituir-se enquanto nova estrutura de pensar e de agir da raça humana, a partir de sua escolha em romper com os princípios tradicionais do passado (pré-moderno) e, principalmente, divorciando-se da religião. Ao tomar essa escolha de "desencantamento" do antigo mundo mítico, irracional ou ritualizado, segundo Weber, abriu-se caminho ao projeto de narrativa cristalizadora do homem civilizado, única linguagem estilizada que permite ignorar os efeitos da morte e consolidar um tempo ilimitado. É essa linguagem que permite desenhar um sujeito oficial e caracterizador de tudo aquilo que faz lembrar o moderno, ela permite gozar de um "progresso" ou de uma vida sem fim.

Em outros termos, a existência do indivíduo racional e civilizado não tem fim em dois sentidos: primeiro (imortalidade) porque nasce em 
um mundo que lhe assegura o direito de viver ilimitadamente ou, pelo menos, com maior liberdade do que outros; e, segundo (sem sentido ou finalidade), porque por ser "homem civilizado", pode se dar ao luxo de se sentir ou não satisfeito com a vida que possui, uma vez que é possível que ele esteja "cansado" dela, mas nunca "pleno" dessa, pois em lhe sendo possibilitadas múltiplas escolhas, não há certeza de nenhuma delas, motivo pelo qual vive um sentimento de vazio contínuo (WEBER, 2004, p. 30-31).

Sobre essas tensões humanísticas do homem racional que foi laicizado pelo progresso, Mate - a partir das teses de Benjamin - também identifica no processo de secularização do tempo moderno, separado da religião, "uma operação em dois tempos". Se, em um deles, percebemos uma "libertação da origem religiosa", em outro, vemos a necessidade de negar, secularmente, os mitos que lhe antecederam. Porém, como consequência dessa "aporética" visão, o sujeito do progresso não obteve êxito em se livrar, completamente, das marcas da religião, muito embora ele continue a tentar, pela via da laicidade formadora dos Estados Soberanos, uma distinção radical entre o simbólico e o racional (o "materialismo histórico e a teologia"). Dessa forma, o grande desafio em (re)memorar o passado dos incivilizados como possibilidade de redenção não gira em torno de haver ou não um feriado religioso como lembrete de que precisamos frequentar locais sagrados ou, ainda, necessitarmos orar aos que já partiram, mas como fazer para que o passado dos "oprimidos" seja revisitado diariamente por todos, em vez de ser visitado poucas vezes ao ano, quando o sentido desse momento é, não raras vezes, interpretado pelos dominadores somente como uma oportunidade de lazer ou de recriação (MATE, 2011, p. 61-62; 71 e ss.; 359-360)?

0 que está em jogo, nesse momento, não é a volta da religião como princípio oculto do Estado ou mesmo uma crítica teórica e pós-moderna que defende a volta de um conservadorismo religioso. Estamos, sim, a tratar de algo ainda mais impreciso e de difícil enunciação: quando o Estado moderno passou a justificar-se por outra narrativa (jurídica e racional), impôs um novo modelo social como forma de governar os homens. Todavia, fez isso quebrando não somente com a ordem religiosa - exemplo esse citado, pois é talvez o mais claro desse processo e o que fez surgir essa estrutura estatal -, mas dissociando-se de qualquer 
lembrança, mito ou imagem que representasse o lado emotivo e frágil dos fenômenos e dos sujeitos.

Somos quase que bombardeados na modernidade com esse dilema do progresso, uma vez que o Leviatã de Hobbes diversificou o seu arsenal de guerra, teve as condições que precisava por meio de seus mecanismos de luz e sombra, para promover uma inovadora investida tecnológica, não exclusivamente contra os primitivos que não atendem a um padrão de racionalidade humanística, mas há máquinas que agora dispensam, por completo, o seu piloto racional/emotivo. Assim, tanto o civilizado quanto o incivilizado (o inimigo e o aliado) são alvos válidos para o que se ampliou como excessiva força coercitiva de dominação social, jurídica e política.

Para Chamayou (2015, p. 42-45; 50 e ss.), são os drones americanos atualmente que oferecem esse tipo de expansão da lógica de guerra dos Estados, pois é possível abater os inimigos de maneira "preventiva", eliminando o fator falho e humano (componente emocional), e antes mesmo que o outro possa se apresentar como "risco" à defesa social. Tratase não mais de dominar ou de fazer guerra para promover a segurança do espaço civilizado hobbesiano, pois há outras formas de se efetuar política na modernidade, não é a guerra como modus da política, mas a guerra político-tecnológico como "esporte", em nome do prazer da caça. Além disso, esses "caçadores" não se submetem a nenhum "processo judicial" ou às convenções de direito internacional, mas respondem a outras instâncias mais cruéis e menos visíveis (MORRISON, 2014b, p. 219 e ss.).

Sem dúvida, não só o Direito, mas todas as objetividades ou narrativas estão voltadas para a tarefa de reencontrar seus espaços de legitimidade, diz Morrison. Isso porque, se a modernidade (ou pós-modernidade, para o autor) teve sucesso em se distanciar das tradições, isto é, se o que resta ao homem em uma pós-modernidade é somente a sua racionalidade, então qual o sentido de vivermos em um mundo que alienou todos os sentidos? ${ }^{16}$ É no mínimo irônico, para o autor, que mesmo havendo uma demanda cada vez maior por parte dos indivíduos que reclamam o Direito como narrativa, como solução aos mais variados problemas sociais, ele não consiga oferecer quase nenhuma saída ao sentimento de vulnerabilidade de boa parte da população mundial (MORRISON, 2016, p. 517, nota 7 ; 518). 
De acordo com Morrison, essa crise institucional da narrativa jurídica dos Estados Soberanos está tão agravada na pós-modernidade que talvez questões basilares acerca "do que é a lei" e para que ela serve não possam ser respondidas, de modo que essa "falta de sentido" do Direito parece expressar somente uma certa dose de "fascismo", que alimenta sua lógica interna. Apesar de ser um mecanismo de estruturação da vida social, o Direito tem por única função, segundo o autor, legitimar o "domínio dos governantes" sobre os governados, como autêntico "processo de dominação". É preciso, pois, ficar atento a esses discursos da modernidade que disputam uma briga pelo poder ou pela autoridade de definir o que deve ou não fazer parte de um determinado projeto construído pela civilização iluminista.

Em que pese ao fato de essas "narrativas iluministas" ou modernas dos Estados Soberanos advogarem pela "paz universal", pela distribuição de riquezas, pelo conhecimento acessível a todos e pela emancipação dos sujeitos por meio da razão, elas têm, sim, por finalidade, segundo Lyotard, causar um efeito oposto, natural a seu método de pesquisa: a repetição e a legitimação das "regras de seu próprio jogo". Além disso, fortalecem as instituições sociais que delas dependem. Assim, essas "grandes narrativas" repetem as mesmas premissas que fundamentam seus dispositivos ou objetividades, a fim de causar uma sensação ilusória de que estamos indo há alguma direção, mas, na verdade, permanecemos correndo em círculos, perseguindo as linguagens usuais de nosso pensar, em vez de definirmos como atitude "pós-moderna" um estado de "desconfiança sobre as metanarrativas" (LYOTARD, 1984, p. xxiii-xxiv; 19-20; 31 e ss.; 36).

Em outra linha argumentativa, mais próxima da Criminologia, Young (2011, p. 84) também está preocupado com essa disputa pelo poder ou pelo reconhecimento intelectual dentro desse campo científico. Para o autor, é assustadora essa falta de criatividade científica e criminológica, pois, quanto mais os recentes fenômenos da modernidade tardia impactam e transformam a sociedade ocidental, menos os criminólogos desejam investir nessa virada cultural. ${ }^{17}$ Assim, acabam recorrendo às fórmulas das ciências sociais e às outras positividades (narrativas tradicionais), no sentido de preservar unicamente a "hegemonia" dessa ciência, entendida 
como crítica e justificando sua necessária passividade como limite epistemológico que não deve ser ultrapassado.

Tal modelo ortodoxo de reflexão criminológica sobre os objetos de pesquisa deixa Young apreensivo com a possibilidade de a Criminologia ser, em verdade, uma antítese à analogia do "toque de Midas", possuindo a "habilidade de transformar ouro em pedra", ao invés de iluminar os múltiplos processos que estão acontecendo nesse novo tecido social. Situação na qual o sistema de recompensas e de identificação dos sujeitos na modernidade tardia está fragmentado e/ou destruído ("caótico"). Dessa forma, segundo o autor, a sociedade moderna terá que escolher entre continuar a procurar por narrativas próprias e subjetivas fora das instituições sociais ou, inversamente, renderem-se às narrativas racionais já deterioradas e se autorrepresentar (enganar), via positivismos (YOUNG, 2011, p. 4-5; 60-63; 83-84).

\section{CONCLUSÃO}

Este artigo objetivou repensar a imaginação de guerra e de morte utilizada pelos Estados soberanos em face do projeto moderno, no sentido de trazer à tona a discussão sobre crimes praticados pelas agências de controle oficial, isto é, os genocídios ocultados pelos Estados-nação e pelos Mercados Globais. Paralelamente, também contestou a passividade da Criminologia contemporânea, de forma a colocá-la em tensão com sua própria disciplina, questionando, assim, seu logos; os crimes que deixou de estudar; os limites dessa disciplina; entre outras responsabilizações políticas e práticas.

Desde uma perspectiva global, tendo em vista a fraqueza e a crise de sentido das narrativas racionais das instituições sociais na modernidade tardia, apresentamos neste trabalho as razões para essa dificuldade das objetividades (a exemplo da lei como objetividade ou finalidade do Estado moderno) não serem mais hábeis a proporcionar uma posição segura dos sujeitos (lato sensu) nos limites circunscritos pela lógica institucional e pelas agências de controle. Por esse motivo, a mudança cultural e do pensamento social na contemporaneidade apresenta, como consequência 
do processo descrito, uma busca constante por subjetividade, em um tempo de incertezas em que não mais se consegue oferecer um sistema de classificações que esteja atualizado com relação àquele projeto, por exemplo, proposto por Durkheim sobre a realidade natural e coercitiva do "fato social" (2007, p. 124-125).

Assim sendo, a crise institucional do Estado moderno, em termos do (des)valor de sua linguagem aponta, paradoxalmente, para um necessário processo de (re)pensar os limites da violência estrutural e dos estilos de vida que valem a pena serem preservados, os quais os Estado Soberanos legitima, pelos mecanismos de luz e sombra, e que busca obscurecer a imagem criminológica dos intelectuais e da própria sociedade, por meio de uma noção de soberania construída pela lógica de guerra. Além disso, que permite outorgar a determinados sujeitos (superiores) a possibilidade de viverem nesses espaços, excluindo e pulverizando outros ditos inimigos.

Embora os mecanismos jurídicos (de luz e sombra) tenham uma função essencial para o Estado, como forma de organização da vida social, a lógica de guerra hobbesiana não deixou de ampliar o seu fundamento, a tal ponto que em nome da proteção da ordem social, as leis se tornaram instrumentos de dominação e de destruição em massa, não só por essas estruturas estatais, mas pelos Mercados Globais. Se o Estado perdeu a sua racionalidade, no sentido de ter sua linguagem contestada pelos novos processos culturais da modernidade tardia, uma vez que a nova norma individual/social é não ter norma, nosso trabalho buscou apresentar essa crise das instituições sociais para além de suas dimensões positivas, jurídicas, filosóficas, políticas, sociológicas, criminológicas, entre outras.

Nessa perspectiva, a (re)descoberta das razões pelas quais possamos nos motivar novamente a crer nessas instâncias de controle dependem da denúncia e da resistência que necessitamos oferecer ao excesso de violência estrutural que é utilizada de forma expansiva na contemporaneidade. Essa criadora de morte, devido à sombra dos conceitos técnico-científicos. Dessa forma, o papel da Criminologia não é pequeno em relação à preocupação, de um lado, com seus limites epistemológicos, mas, de outro, com sua negligência acadêmica e histórica (responsabilidade político/prática) em descrever e reproduzir as Grandes Narrativas do progresso dos 
vencedores, em vez de prover guarida aos sujeitos, em claro estado de exceção permanente.

A perplexidade global e desafiadora dos Estados Soberanos e do próprio pensamento criminológico perpassa pela discussão da dualidade presente nos instrumentos teóricos e políticos de suas análises (o poder de iluminar e de obscurecer esse ou outro determinado propósito/ interesse), isto é, o quanto a sociedade terá condições de resistir aos dogmatismos do Direito e do progresso como racionalidade primeira e fundamentadora das ações dos sujeitos. Poderíamos também pensar se, em decorrência de uma fragmentação total dessas narrativas objetivas, viveremos - se já não estamos a vivenciar tal processo - situações de contínua descontinuidade individual/social, cujo resultado poderá ser próximo da anarquia social e de outros eventos de autodestruição, haja vista que, se existem problemas nas agendas e não especificamente nas agendas impostas pelos Estados Soberanos, é oportuno refletirmos sobre o que possa vir a surgir na falta dessas instituições e em termos de populismos penais e discursos de ódio, na qualidade de fato natural das novas dinâmicas sociais (retrocesso); especialmente em prejuízo de processos democráticos.

Tal preocupação não pretende defender uma absoluta confiança nas instituições sociais e em suas linguagens, mas assinalar a tarefa esquecida, por parte da academia científica, e de inúmeros atores sociais na modernidade tardia: a não percepção da parte invisível dos conceitos racionais. Em absoluto, não desejamos descartar por completo o projeto do progresso construído pela própria civilização. É necessário, porém, organizar essa plataforma iluminista, no sentido de averiguar suas inspirações, pressupostos, preconceitos e entender como podemos (re) pensar, dentro da Criminologia e para além dela, o quão visível e precisa é nossa compreensão, e o quão de modo invisível e impreciso nossas teorias do conhecimento político/prático têm refletido uma mecânica tediosa e pouco inovadora, dentro do cosmo de legitimidade social, institucional, entre outras. 


\section{NOTAS}

1 Salientamos ao leitor o motivo pelo qual escolhemos utilizar uma obra comentada das teses de Walter Benjamin ("Sobre o conceito de história"), ao invés de referirmos a "obra oficial" do autor. Isso acontece devido as singulares históricas e reflexivas entre a vida e a produção intelectual do Benjamin. Nesse sentido, segundo Mate, um de seus tradutores e pesquisadores contemporâneos, Benjamin foi mais um judeu perseguido pela Alemanha nazista durante o Holocausto, preferindo cessar prematuramente sua vida, em vez de ser executado pelos "vitoriosos" da ideologia antissemita daquele período. Assim, uma série de escritos do autor foram perdidos durante esse evento - muitos jamais recuperados. Por outro lado, Benjamin foi auxiliado por amigos próximos antes de sua morte, à exemplo de Hannah Arendt, amiga e parente do autor, que recebeu uma cópia dessas teses e que, posteriormente, as encaminhou para Adorno. Desse modo, Adorno e Horkheimer decidem publicá-las em 1942, em respeito à qualidade literária e a resistência histórica e política do autor. Ademais, não seria demasiado compreendermos que tais teses são atemporais, isto é, mais do que apenas escritos aleatórios e a descrição momentânea e subjetiva do contexto e a forma como foram edificadas, elas refletem, sim, tanto um determinado modo de se fazer política na modernidade quanto as consequências extraídas do "fascismo" higienista, esse ancorado na noção de uma máquina acelerada em busca do progresso técnico-científico. Ademais, tais teses constituem uma espécie de "resposta política" oferecida por um filósofo no momento em que, especialmente na Europa, "não havia nenhum lugar para a esperança" (MATE, 2011, p. 9 e ss.; 17-18). É justamente a resistência de Benjamin contra a ideologia do dominador/ colonizador que transforma esses trabalhos em algo tão precioso, pois foi capaz de vincular um determinado método de investigação (genealogia da história e de suas estratégias de poder e dominação) com a sua própria história de vida. Finalmente, por não existir uma obra oficial de Benjamin sobre essas teses, optamos por empregar a obra de Mate, haja vista que ela não apenas traz a tradução de muitos dos escritos de Benjamin recuperados pós-Holocausto, mas também acresce comentários tanto acerca do cenário ao qual foi escrito quanto em relação às possíveis interpretações que dela podem ser extraídas.

2 Sobre a importância das instituições ou do "fato social" para o modus de regramento e de encontro da coesão social, isto é, da função que devem exercer naturalmente e coercivamente na sociedade, em prol da divisão do trabalho por meio de vínculos de solidariedade social, solidificados pelo Direito Penal e pelo Direito Civil, bem como na construção de uma "consciência coletiva", ver (DURKHEIM, 2016, p. 62 e ss.; 67-70; 74; 84).

3 De acordo com Ferrajoli, para que a Criminologia tenha condições de mais "prevenir" do que "reprimir" os danos desastrosos que a "criminalidade do poder provoca", os crimes praticados pelos Estados Soberanos e pelos Mercados Globais, ela precisa ser uma disciplina autônoma e não "auxiliar" da Ciência ou do Direito Penal (FERRAJOLI, 2014, p. 86 e ss.).

4 Acerca dessa discussão, ver Bernal Sarmiento (et al., 2014, p. 55 e ss.).

5 Salientamos também a aparente filantrópica (estratégia de poder) com que as corporações escondem as suas ações: esses "comunistas liberais", "dão com uma das mãos o que primeiro agarram com a outra" (ŽIŽEK, 2014, p. 28; 36-37).

6 Gostaríamos apenas de salientar essa virada paradigmática do Leviatã Contemporâneo: enquanto o controle panóptico dos indivíduos era concretizado por dispositivos racionais, a "boa legislação" que deveria conduzir a vida dos homens (BECCARIA, 1999, p. 126; 128-129), fundada em uma noção contratualista (HOBBES, 1983, p. 89 e ss.; 91); levando em consideração o neoliberalismo como um novo sistema normativo, podemos perceber que as políticas do medo social (iluminista) do Leviatã hobbesiano transformou-se em uma nova realidade que governa a sociedade moderna, atribuindo o projeto de segurança da ordem social ao indivíduo que deve, como diz Dardot e Laval, assumir a culpa de seu fracasso (DARDOT e LAVAL, 2016, p. 350; 365-368).

7 Outro relato invisibilizado pela marcha do progresso técnico-científico e que, por isso, merece nosso destaque é o espaço de denúncia contra a cultura paternalista e a criminalização dos direitos das mulheres, que tem sido realizada pelo movimento feminista, especialmente dentro da Criminologia, nas últimas décadas. Nesse sentido, explica Young, que um dos temas esquecidos 
pela Criminologia Crítica ou radical de 1973 foi justamente os estudos sobre gênero e vitimização, consolidados pelas diversas ondas do pensamento político-social feminista. Por esse motivo, a "nova Criminologia" da modernidade tardia ganhou inúmeros olhares e perspectivas diferenciadas que procuram construir novas abordagens de pesquisa, para além de uma metodologia criminológica, capaz somente de refletir sobre o crime e o controle social, do ponto de vista ortodoxo ou estatístico (YOUNG, 1998, p. 259 e ss.).

8 Sobre esse tema, apontamos (MORRISON, 2012, p. 101 e ss.; 107; 134), especialmente no sentido de trazer luz a essas histórias não contadas pelos crânios estudados por Lombroso, que foram o custo do progresso hobbesiano, isto é, o “caldo de cultivo material da criminologia positivista”. É de admirar-se, segundo Morrison, que dentro de um projeto tão civilizado de mundo, "se estavam recolhendo crânios", com tanta naturalidade.

9 Essa analogia foi realizada a partir do "ser-aí" que é o "ser-no-mundo", que nasce em direção à morte, não tendo outra escapatória, do que viver no mundo e não em si mesmo (HEIDEGGER, 2005, p. 90-91).

10 Um exemplo de uma pronta crença constitutiva da sociedade moderna seria os populismos penais. As prontas crenças é o que há de pior em relação à invisibilidade projetada pelos mecanismos racionais de luz e sombra dos Estados Soberanos, pois são as negações da possibilidade de pensarmos de forma desconstruir um determinado sistema doxal e já naturalizado no tecido social. Quando um sujeito diz: não é assim, por que você não pensa como nós, não há outro jeito (e faz isso sobre a crença do panóptico, certamente), ele não está conseguindo refletir racionalidade sobre aquilo que estou dizendo - caso apresentemos uma versão discursiva (possibilidade) contrária à dele -, mas utiliza automaticamente as suas prontas crenças, de modo a negar, naturalmente, meu questionamento heterodoxo, pois foi treinado pelas instituições a pensar dentro dos limites de invisibilidade, impostos por elas e por suas estratégias de poder. Dito de outro modo, as prontas crenças são negações ou resistências à possibilidade de imaginarmos, algo de forma contrária, às crenças ou doxas sociais, já naturalizadas pela história do progresso genocida, como um dado normal e necessariamente coercitivo da realidade social.

11 É interessante perceber que, talvez, outros eventos possam apresentar-se como preparatórios de crimes massivos contra a humanidade, como o encarceramento em massa, os populismos penais, os discursos de ódio, entre outras possíveis situações.

12 É importante ressaltar que não estamos a desprestigiar a relevância da construção de uma nova Criminologia, realmente crítica e global, isto é, que tenha condições de estudar os crimes praticados pelos mais poderosos (Estados Soberanos, Mercados Globais, etc.). No entanto, se nossa intenção é pensar na formação de uma Criminologia para além da Criminologia, o exercício verdadeiramente crítico não é apenas o que pretende ser criativo ou inovador nesse campo de estudo, mas crítico, enquanto a validade da construção história e epistemológica da Criminologia, que não deve ser abandonada por completo, sem demais questionamentos. Além disso, não podemos presumir que um novo tópico urgente de análise não poderá surgir no futuro e, portanto, se fará necessário desenvolver um novo ramo dentro da ciência criminológica; não podemos deixar de lado essa hipótese, dado apenas o fato de que ela ainda não se materializou, no futuro da sociedade moderna.

13 Embora haja diferenças consideráveis em relação à descrição do tempo em que vivemos: "modernidade líquida” (BAUMAN, 2003, p. 113), “modernidade reflexiva” (BECK, 1997, p. 12; 16; 24 e ss.; 154), modernidade tardia (HAYWARD, 2004, p. 173), entre outras propostas. Quando utilizamos o termo modernidade, entendemos que não é possível estarmos em uma suposta pós-modernidade, o que implicaria que os problemas da modernidade tivessem sido superados pela nova dinâmica pós-modernista. No entanto, como esclarece Lyotard, a modernidade é uma perpétua reescrita sobre si mesma e para além dela (LYOTARD, 1997, p. 35).

14 Sobre o descontrole social, citamos os relevantes trabalhos da Criminologia Cultural: Ferrell (1996), Young (2007, p. 3-6; 12-13), Hayward (2004, p. 152 e ss.; 191-192), Hayward e Young (2007, p. 102 e ss.), Hayward e Presdee (2010). Em outra perspectiva de análise, Fariñas Dulce (2018, p. 344 e ss.) também aborda esse novo contexto social e despótico que estamos a viver na contemporaneidade, uma vez que o modo de governo neoliberal propõe uma normalização do conceito de anomia de Durkheim, isto é, uma verdadeira "anomia constitucional" que pro- 
cura desvalorizar e desregrar os direitos básicos e fundamentais da vida coletiva, a exemplo do trabalho, da liberdade, da justiça, da propriedade, etc.

15 Sobre esses slogans que fazem da Democracia um conceito "interpretativo", ver (DWORKIN, 2014, p. 579 e ss.).

16 No original: Consequently, this world might actually be meaningless without the simple assumption and tradition that it is meaningful, sem tradução em língua portuguesa (Nota de Tradução). Por outro lado, eis o desafio que nos impõe Young, em relação à percepção desse mundo social (o seu sentido) na modernidade tardia: como podemos medir, de forma objetiva e fixa, um tempo, na qual todas essas definições estão em constante flutuação (YOUNG, 2011, p. 60-61)? Dito de outra forma, se não existe sentido em vivermos em um mundo que rompeu com todos os sentidos, como medir esse não sentido que está sempre se transformando ou sendo sempre alterado em questão de segundos (velocidade)? Até que ponto a imaginação dos criminólogos possui a condição humana capaz de acompanhar essa tensão cultural e flutuante na modernidade tardia?

17 No original, cultural turn, traduzido para o português como virada cultural (NT).

\section{REFERÊNCIAS}

BARAK, Gregg. Unchecked Corporate Power: Why the crimes of multinational corporations are routinized away and what we can do about it. New York: Routledge, 2017.

BAUMAN, Zygmunt. Comunidade: A busca por segurança no mundo atual. Tradução de Plínio Dentzien. Rio de Janeiro: Jorge Zahar, 2003.

BAUMAN, Zygmunt. Vida a crédito: Conversas com Citlali Rovirosa-Madrazo. Tradução de Alexandre Werneck. Rio de Janeiro: Jorge Zahar, 2010.

BECCARIA, Cesare. Dos delitos e das penas. Tradução de J. Cretella Jr. e Agnes Cretella. 2. ed. São Paulo: Revista dos Tribunais, 1999.

BECKER, Howard Saul. Outsiders: Studies in the sociology of deviance. New York: The Free Press, 1963.

BERNAL SARMIENTO, C. E. (et al.). Más Allá de la Criminología. Un Debate Epistemológico sobre el Daño Social, los Crímenes Internacionales y los Delitos de los Mercados. In: Delitos de los Estados, de los Mercados y Daño Social: Debates en Criminología Crítica y Sociología jurídico-penal. RIVEIRA BEIRAS, Iñaki (coord.). Barcelona: Anthropos Editorial; Observatori del Sistema Penal i els Drets Humans de la Universitat de Barcelona (OSPDH), 2014.

BERGALLI, Roberto. Diálogos sobre Criminología, Genocidio y Daño Social com Wayne Morrison, Eugenio Raúl Zaffaroni y Roberto Bergalli. In: Delitos de los 
Estados, de los Mercados y Daño Social: Debates en Criminología Crítica y Sociología jurídico-penal. RIVEIRA BEIRAS, Iñaki (coord.). Barcelona: Anthropos Editorial; Observatori del Sistema Penal i els Drets Humans de la Universitat de Barcelona (OSPDH), 2014.

BOURDIEU, Pierre. Questões de Sociologia. Rio de Janeiro: Marco Zero Limitada, 1983.

BOURDIEU, Pierre. Sobre a televisão. Tradução de Maria Lúcia Machado. Rio de Janeiro: Jorge Zahar Ed., 1997.

BOURDIEU, Pierre. (1930-2002). Sobre o Estado: Cursos no Collège de France (1989-92). Tradução de Rosa Freire d'Aguiar. 1 ed. São Paulo: Companhia das Letras, 2014.

CHAMAYOU, Grégoire. Teoria do Drone. Tradução de Célia Euvaldo. São Paulo: Cosac Naify, 2015.

DARDOT, Pierre; LAVAL, Christian. A nova razão do mundo: ensaio sobre a sociedade neoliberal. Tradução de Mariana Echalar. 1 ed. São Paulo: Boitempo, 2016.

DURKHEIM, Émile. As regras do método sociológico. Tradução de Paulo Neves. 3 ed. São Paulo: Martins Fontes, 2007.

DURKHEIM, Émile. Da divisão do trabalho social. Tradução de Andréa Stahel M. da Silva. São Paulo: EDIPRO, 2016.

DURKHEIM, Émile. 0 suicídio: estudo de sociologia. Tradução de Andréa Stahel M. da Silva. São Paulo: EDIPRO, 2014.

DWORKIN, Ronald. A raposa e o porco-espinho: justiça e valor. Tradução de Marcelo Brandão Cipolla. São Paulo: WMF Martins Fontes, 2014.

FARIÑAS DULCE, María José. Neoliberalismo versus democracia. Eunomía. Revista en Cultura de la Legalidad. no14, abril/setembro, p. 342-352, 2018.

FERRAJOLI, Luigi. Criminología, Crímenes Globales y Derecho Penal. El Debate Epistemológico en la Criminología Contemporânea. In: Delitos de los Estados, 
de los Mercados y Daño Social: Debates en Criminología Crítica y Sociología jurídico-penal. RIVEIRA BEIRAS, Iñaki (coord.). Barcelona: Anthropos Editorial; Observatori del Sistema Penal i els Drets Humans de la Universitat de Barcelona (OSPDH), 2014.

FERRELL, J. Crimes of style: urban graffiti and the politics of criminality. Boston: Northern University Press, 1996.

FREUD, Sigmund. O mal-estar na civilização, novas conferências introdutórias à psicanálise e outros textos (1930-1936). Tradução de Paulo César de Souza. São Paulo: Companhia das Letras, 2010.

FRIEDRICHS, David O. Crimes of the powerful and the definition of crime. In: GREGG, Barak (editor). The Routledge International Handbook of the Crimes of the Powerful. London: Routledge, 2015.

GARLAND, David. Disciplining Criminology? Revista Sistema Penal e Violência, Porto Alegre, vol. 1, nำ1, jul./dez., p. 114-125, 2009.

HEIDEGGER, Martin. Ser e tempo. Parte I. Tradução de Marcia Sá Cavalcante Schuback. 15. ed. Petrópolis: Vozes, 2005.

HAYWARD, Keith J. City limits: crime, consumer culture and the urban experience. London: Cavendish, 2004.

HAYWARD, Keith J; YOUNG, Jock. Cultural Criminology. In: MAGUIRE, Mike et al. The Oxford handbook of criminology. London/New York: Oxford University Press, 2007.

HAYWARD, Keith J; PRESDEE, Mike. Framing Crime: Cultural Criminology and the Image. New York: Routledge, 2010.

HILLYARD, Paddy; TOMBS, Steve. Beyond criminology? In: HILLYARD, Paddy; TOMBS, Christina Pantazis Steve; GORDON, Dave. Beyond Criminology: Taking Harm Seriously. London: Fernwood Publishing, 2004.

HILLYARD, Paddy; TOMBS, Christina Pantazis Steve; GORDON, Dave. Beyond Criminology: Taking Harm Seriously. London: Fernwood Publishing, 2004. 
HOBBES, Thomas. Leviatã. Matéria, forma e poder de um Estado eclesiástico e civil. Tradução de João Paulo Monteiro e Maria Beatriz Nizza da Silva. 3 ed. São Paulo: Abril Cultural, 1983.

KELSEN, Hans. Teoria pura do Direito: introdução à problemática científica do direito. Tradição de J. Cretella Jr. e Agnes Cretella. 4 ed. São Paulo: Revista dos Tribunais, 2006.

LYOTARD, Jean-François. The Postmodern Condition: A Report on Knowledge. Minneapolis: University of Minnesota Press, 1984.

LYOTARD, Jean-François. 0 Inumano: considerações sobre o tempo. Tradução de Ana Cristina Seabra e Elisabete Alexandre. 2 ed. Lisboa: Estampa, 1997.

MATE, Reyes. Meia-noite na história: comentários às teses de Walter Benjamin. Tradução de Nélio Schneider. São Leopoldo, RS: UNISINOS, 2011.

MATE, Reyes. Contra lo políticamente correcto: política, memoria, justicia. 1 ed. Buenos Aires: Altamira, 2006.

MILLS, C. Wright. The sociological imagination. New York: Oxford University Press, 1959.

MBEMBE, Achille. Necropolítica. In: Necropolítica seguido de Sobre el Gobierno Privado Indirecto. Tradução e edição de Elisabeth Falomir Archambault. Madri: Melusina, 2011, p. 17-76.

MORRISON, Wayne. Theoretical Criminology: from modernity to postmodernism. London: Cavendish Publishing Limited, 1995.

MORRISON, Wayne. Criminología, civilización y nuevo orden mundial. Barcelona: Anthropos Editorial; Observatori Del Sistema Penal i els Drets Humans de la Universitat de Barcelona, 2012.

MORRISON, Wayne. La Imaginación Criminológica Bajo la Globalización: Recordando lo Desaparecido. In: Delitos de los Estados, de los Mercados y Daño Social: Debates en Criminología Crítica y Sociología jurídico-penal. RIVEIRA BEIRAS, Iñaki (coord.). Barcelona: Anthropos Editorial; Observatori del Sistema Penal i els Drets Humans de la Universitat de Barcelona (OSPDH), 2014a. 
MORRISON, Wayne. Diálogos sobre Criminología, Genocidio y Daño Social com Wayne Morrison, Eugenio Raúl Zaffaroni y Roberto Bergalli. In: Delitos de los Estados, de los Mercados y Daño Social: Debates en Criminología Crítica y Sociología jurídico-penal. RIVEIRA BEIRAS, Iñaki (coord.). Barcelona: Anthropos Editorial; Observatori del Sistema Penal i els Drets Humans de la Universitat de Barcelona (OSPDH), 2014b.

MORRISON, Wayne. Jurisprudence: from the Greeks to post-modernism. Abingdon, Oxon: Routledge, 2016.

RIVEIRA BEIRAS, Iñaki . Diálogos sobre Criminología, Genocidio y Daño Social com Wayne Morrison, Eugenio Raúl Zaffaroni y Roberto Bergalli. In: Delitos de los Estados, de los Mercados y Daño Social: Debates en Criminología Crítica y Sociología jurídico-penal. RIVEIRA BEIRAS, Iñaki (coord.). Barcelona: Anthropos Editorial; Observatori del Sistema Penal i els Drets Humans de la Universitat de Barcelona (OSPDH), 2014.

SANTOS, Boaventura de Sousa. Pela mão de Alice: o social e o político na pósmodernidade. 7 ed. São Paulo: Cortez, 2000.

SCHOSHANA, Felman. 0 inconsciente jurídico: julgamentos e traumas no século XX. Tradução de Ariani Bueno Sudatti. São Paulo: EDIPRO, 2014.

WEBER, Max. Ciência e Política: Duas Vocações. Tradução de Leonidas Hegenberg e Octany Silveira da Mota. São Paulo: Cultrix, 2004.

WEBER, Max. Sociologia das religiões. Tradução de Cláudio J. A. Rodrigues. 1 ed. São Paulo: Ícone, 2010.

YOUNG, Jock. Writing on the Cusp of Change: A New Criminology for an Age of Late Modernity. In: WALTON, Paul; YOUNG, Jock (ed.). The New Criminology Revisited. Nova York: Palgrave Macmillan, 1998.

YOUNG, Jock. The vertigo of late modernity. London: SAGE, 2007.

YOUNG, Jock. The criminological imagination. Cambridge: Polity Press, 2011.

ZAFFARONI, Eugenio. Rául. A questão criminal. Tradução Sergio Lamarão. 1. ed. Rio de Janeiro: Revan, 2013. 
ZAFFARONI, Eugenio. Rául. Diálogos sobre Criminología, Genocidio y Daño Social com Wayne Morrison, Eugenio Raúl Zaffaroni y Roberto Bergalli. In: Delitos de los Estados, de los Mercados y Daño Social: Debates en Criminología Crítica y Sociología jurídico-penal. RIVEIRA BEIRAS, Iñaki (coord.). Barcelona: Anthropos Editorial; Observatori del Sistema Penal i els Drets Humans de la Universitat de Barcelona (OSPDH), 2014.

ŽIŽEK, Slavoj. Violência: seis reflexões laterais. Tradução de Miguel Serras Pereira. São Paulo: Boitempo, 2014.

Recebido em: 25-11-2018

Aprovado em: 26-10-2020

\section{Álvaro Filipe Oxley da Rocha}

Pós-doutorado pela Kent University - UK (Reino Unido). Doutor em Direito Público - UFPR (2002). Mestre em Ciência Política, pela UFRGS, (1999). Bacharel em Direito pela PUC-RS. Pesquisador Associado do NUPESAL - IFCH - UFRGS; Parecerista e Consultor ad-hoc do CNPq / CAPES - MEC.; Vice-Presidente do Instituto Brasileiro de Criminologia Cultural (www.criminologiacultural.com. br). Professor do Ensino Superior (20 anos de experiência: Graduação e Pósgraduação nas áreas de Criminologia, Teoria e Sociologia do Direito (Introdução, História e Antropologia), Ciência Política, Relações Internacionais, Direito Constitucional e Administrativo, Sociologia do Crime e das Instituições de Controle Social. Orientador e Pesquisador nos níveis de Doutorado, Mestrado e Graduação (TCCs). Staff Member da Kent University - SSPSSR, para as Universidades de Ghent-Bélgica, de Atenas - Grécia, Universidade do Porto Portugal, e ELTE University - Budapeste, Hungria. Membro das associações internacionais: AIC, ACS, e CLS, e do CONPEDI. Foi Pesquisador líder no GEPCRIM e no Grupo de Pesquisa Fundamentos de Criminologia, ambos no PPGCCRIM da PUC-RS, integra o Grupo de Estudos Magistratura, Sociedade e Política, do PPG em Sociologia do IFCH da UFRGS. E-mail: oxleyalvaro37@gmail.com

\section{Tiago Lorenzini Cunha}

Doutorando em Ciências Criminais pela PUCRS, na linha de violência, crime e segurança pública (2017-2020). Mestre em Ciências Criminais pela Pontifícia Universidade Católica do Rio Grande do Sul (2016). Pós-graduado no curso de especialização em Direito Penal e Política Criminal: Sistema Constitucional e Direitos Humanos pela Universidade Federal do Rio Grande do Sul (2015). Graduado em Direito pela Pontifícia Universidade Católica do Rio Grande do Sul (2014). Atualmente é bolsista CAPES-Print, com vínculo de pesquisa 
com o Departamento de Direito de Queen Mary University of London, na qualidade de pesquisador associado durante o período de doutorado sanduíche (2019/2020). Faz parte do Grupo de pesquisa Direito à Verdade e à Memória e Justiça de Transição da PUCRS. Parecerista da Revista Brasileira de Ciências Criminais (RBCCrim). Membro da Diretoria Executiva do Instituto Brasileiro de Criminologia Cultural. Tem experiência na área de Direito, com ênfase em Direito Penal e Criminologia. Advogado criminalista. Tem se dedicado aos temas: a justificação do poder punitivo estatal perante os fins do direito penal material; a crise das Grandes Narrativas da modernidade e o seu impacto nas esferas de poder e de controle institucional; a ressignificação de categorias como crime, controle social e sistema de justiça criminal na modernidade tardia; e o estudo do ativismo dos agentes do Estado brasileiro sob o foco de análise da Criminologia Cultural. E-mail: tiagolorenzini@hotmail.com

UniversidadeFederal do Rio Grande do Sul, Instituto de Filosofiae Ciências Humanas. AC Campus UFRGS Agronomia. CEP 91501970 - Porto Alegre, RS 
